OPEN ACCESS

Edited by:

Puneet Singh Chauhan,

National Botanical Research Institute

(CSIR), India

Reviewed by:

Miguel A. Aon,

National Institute on Aging $(\mathrm{NIH})$,

United States

Khawar Jabran,

Duzce University, Turkey

*Correspondence:

Harsimran K. Gill

harsimrangill.pau@gmail.com

Specialty section:

This article was submitted to Crop Science and Horticulture,

a section of the journal

Frontiers in Plant Science

Received: 05 May 2017

Accepted: 17 August 2017 Published: 01 September 2017

Citation:

Gill HK, Aujla IS, De Bellis L and

Luvisi A (2017) The Role of Soil

Solarization in India: How an

Unnoticed Practice Could Support

Pest Control. Front. Plant Sci. 8:1515.

doi: 10.3389/fp/s.2017.01515

\section{The Role of Soil Solarization in India: How an Unnoticed Practice Could Support Pest Control}

\author{
Harsimran K. Gill ${ }^{*}$, Iqbal S. Aujla², Luigi De Bellis ${ }^{3}$ and Andrea Luvisi ${ }^{3}$ \\ ${ }^{1}$ Department of Entomology, Cornell University, Ithaca, NY, United States, ${ }^{2}$ Department of Plant Pathology, Punjab \\ Agricultural University, Ludhiana, India, ${ }^{3}$ Department of Biological and Environmental Sciences and Technologies, University \\ of Salento, Lecce, Italy
}

Plant protection represents one of the strategies to fill the yield gap and to achieve food security, a key topic for India development. Analysis of climate risks for crops indicates that South Asia is one of the regions most exposed to the adverse impact on many plants that are relevant to inhabitants exposed to food safety risks. Furthermore, accumulation of pesticide residues in the aquatic and other ecosystems is becoming a significant threat in India. These perspectives require to develop programs of crop protection that can be feasible according to Indian rural development and pollution policy. Here we review the research works done on soil solarization in India. Soil solarization (also called plasticulture) is an eco-friendly soil disinfestations method for managing soil-borne plant pathogens. This is the process of trapping solar energy by moist soil covered with transparent polyethylene films and chemistry, biology and physical properties of soil are involved in pest control. So far, this technique is applied in more than 50 countries, mostly in hot and humid regions. India has 29 states and these states fall under five climatic zones, from humid to arid ones. We report pest management application in different climatic zones and their effects on production, weeds, nematodes, and pathogenic microorganisms. The analysis of soil temperatures and crop protection results indicate as environmental requirement for soil solarization fits in most of Indian rural areas. Soil solarization is compatible with future Indian scenarios and may support Indian national food security programs.

Keywords: soil-borne pathogens, food safety, fungi, crop protection, plastic film mulching

\section{THE NEED OF SUSTAINABLE CROP PROTECTION IN INDIA}

The yield gap is a hiatus between actual production and the best yield achievable using genetic material and available technologies and management. It strongly depends on the possibility of farmers to access most appropriate genetic resources (seeds, plants), natural inputs (suitable soil and water), knowledge (practices and information), and technology (pest management, mechanization) (Godfray et al., 2010). This gap is not irrelevant and, in many areas worldwide, represents one of the main factors that prevent the achievement of food security (PinstrupAndersen, 2009). In parts of Southeast Asia, where water for agricultural purposes is usable, it has been estimated that average production of rice is just more than half of potential production using optimized input (Cassman, 1999). 
Plant protection represents one of the strategies to fill the yield gap. Control of pests and microbial pathogens, at least applying agronomic methods, is de-facto mandatory, and the role of chemicals in agriculture in the last century is crucial. Worldwide, the pesticide consumption is about two million tons per year. India, with its average pesticide usage rate of $0.5 \mathrm{~kg}$ per hectare, contributes $4 \%$ to the world's total pesticide consumption. More than $80 \%$ of the agrochemicals used in India are classified as insecticides, while 15\% are herbicides and $2 \%$ are fungicides (Agarwal et al., 2015). Though the pesticide consumption rates are high in the most productive areas of India and comparable to the high amounts used per hectare in the other parts of the world (Europe or United States), vast territories of poor crop production areas with nil or very low pesticide consumption pulls down the national average. With the emphasis on food security, these territories are the focus of the Indian government for realizing the objectives of National Food Security Act. Even in the high productivity areas, higher yielding varieties and better management practices are being deployed to further improve the marginal gains in rice, wheat, maize, pulses, and other crops. India has started reaping benefits of these efforts (Ray et al., 2013). Pesticides have played a significant role in realizing these benefits. But this increased pesticide usage has led to the accumulation of pesticide residues in the aquatic and other ecosystems. Contamination of drinking water sources with these pesticide residues is becoming a significant threat in India (Pillai and Rao, 1974; Khan et al., 1997, 2000; Gill and Garg, 2014; Agarwal et al., 2015). Moreover, beside economic costs for their application (not irrelevant for many populations, such those of developing countries), the environmental impact of agrochemicals are assuming a central role in public debate worldwide and the search of environmental friendly protection techniques is primary (Gill and Garg, 2014).

Among plant protection techniques, soil solarization (also called plasticulture) may play a significant role in the next years because it could be considered a sort of paradigm of sustainable crop protection method, particularly useful for countries such as India. The low environmental impact (mainly due to plastic film disposal, avoidable if biodegradable films are used), the wide-spectrum of actions against pathogen and the environmental requirement for effective solarization treatments seem fit perfectly with the Indian needs of plant protection. Moreover, the low costs of investment and application (mainly limited to soil mulching machine), the no-need of high-tech infrastructures or farm ability, the yield increase and perspective in climate changes could strongly support underdeveloped productive areas of India and sustain their food security.

\section{SOIL SOLARIZATION: A BRIEF COMPENDIUM}

First reports of soil solarization practice date back to late ' 800 in German Empire and United States, where it started being used commercially. Solarization is a chemical-free way of controlling pests such as pathogenic microorganisms (mainly fungi, bacteria, and nematodes), insects, and wild plants in the soil before crops planting (Katan, 1987; McGovern and McSorley, 1997; Gill et al., 2009). Solarization technology does not release any dangerous chemical residue in the ground; it is a safe, simple, effective, and eco-friendly tool for the home gardens and fields (Kapoor, 2013). This pre-plant method involves soil heating by capturing solar radiations for 4-6 weeks during the summer time when the soil receives the maximum sunlight. Soil intercept the energy radiated from the sun and its temperature rise to the level that is deadly to many soil-borne pathogens. It improves soil texture and the nutrients availability in the soil which are essential for plants growth and development. Unfortunately, in India, most of the farmer and rural people are not aware of the applications of soil solarization technology. There are a need of training workshops and mass awareness programmers for popularizing this technology among the farmers and rural communities (Kapoor, 2013). The primary commercial use of solarization involved sunny and warm lands. The mechanism of action is based on the increased soil temperature (commonly in the range of $45-55^{\circ} \mathrm{C}$ ) at soil depth of $5-\mathrm{cm}$ underneath transparent polyethylene sheets causes plant pathogens mortality (Katan, 1981). Besides the reduction in soil-borne pathogens, soil solarization also leads to increased growth response (IGR) of plants (Katan, 1981; Horiuchi, 1984). Soil solarization also integrates well with other techniques such as mulching, and soil amendments to enhance its overall effectiveness against pests and, increase crop yield (D’Addabbo et al., 2010).

Diversity of soil, climate, and social and economic values of the human population leads to the variety of the cultivated crops in India. Rice, wheat, barley, maize, cotton, groundnut, sugarcane, pulses, tobacco, pigeon pea, soybean, sorghum, cherry, strawberry, apple, and tomatoes are most commonly cultivated crops in India. However, different crops are grown in different states of India depending on the soil type, climate conditions, temperature, and rainfall, etc. More information on the main crops grown in India can be accessed at these web links ${ }^{1,2}$. Few commonly associated weeds in these cultivated crops include Phalaris minor, Cyperus rotundus, Cynodon dactylon, Acrachne racemosa, Avena spp., and Orobanche spp. Most common soil-borne fungal and nematode pathogens include Sclerotinia spp., Rhizoctonia spp., Phytophthora spp., Macrophomina spp., Fusarium solani, Fusarium oxysporum, Pythium spp., Sclerotium spp., Meloidogyne incognita, Heterodera spp., Pratylenchus spp., and Rotylenchus spp.

\section{Weeds Control}

The literature points to the success of solarization in managing weeds even up to $98 \%$ in corn (Ahmad et al., 1996), while on the other hand $90 \%$ crop damage due to weeds alone is also reported in unsolarized control plots (Elmore et al., 1997). Worldwide, solarization has managed to control annual weeds such as annual bluegrass, Ageratum spp., Amaranthus spp., barnyard grass, cogongrass, common purslane, Digitaria spp., Portulaca spp., redroot pigweed, Setaria spp., and many others (Daelemans, 1989; Benlloglu et al., 2005). The weeds elimination also prevents

\footnotetext{
${ }^{1}$ http://www.gktoday.in/major-crops-of-india/

${ }^{2}$ https://testbook.com/blog/crops-in-india-gk-notes-pdf/
} 
the growth and widespread of pathogenic microorganisms or insects which may spend their lifecycle on wild plants (Stapleton and DeVay, 1986). Generally, winter wild plants are easier to eliminate, whereas summer wild plants such as Cyperus spp. or Convolvulus arvensis showed a good resistance against the disinfection treatment (Katan, 1981).

\section{Microbial Pathogen Control}

Damping-off, root rot, and wilt are economically damaging plant diseases. Soil solarization has managed to manage the causal organisms (fungus or bacteria) of these diseases. Few successfully managed soil-borne fungal and bacterial in different cropping systems include Rhizoctonia spp., Fusarium spp., Sclerotinia spp., Macrophomina spp., Phytophthora spp., Verticillium spp., Agrobacterium tumefaciens, Clavibacter michiganensis, Pythium spp., and Streptomyces scabies (Ahmad et al., 1996; McGovern and McSorley, 1997; Chellemi and Mirusso, 2006; Gelsomino et al., 2006).

\section{Nematodes and Insect Control}

Solarization can manage broad range of nematodes (roundworm or threadworm) like spiral nematode (Helicotylenchus digonicus), root-knot nematode, reniform nematode (Rotylenchulus reniformis), ring nematodes (Mesocriconema spp.), pin nematode (Paratylenchus hamatus), lesion nematode (Pratylenchus spp.), cyst nematode (Heterodera glycines Ichinohe), sting nematode (Belonolaimus spp.), dagger nematodes (Xiphinema spp.), stubby root nematode (Paratrichodorus minor), stem and bulb nematode (Ditylenchus dipsaci Kuhn.), potato cyst nematode (Globodera rostochiensis), northern root-knot nematode (Meloidogyne hapla), and sugar beet cyst nematode (Heterodera schachtii) (Abdel-Rahim et al., 1988; Stapleton and Heald, 1991; Elmore et al., 1997; McGovern and McSorley, 1997). Insects (mainly stored grain pests) have been controlled by soil solarization to some extent as well. Soil solarization was observed to change soil chemistry which may weaken or kill some kinds of soil organisms (McFarlane, 1989; Elmore et al., 1997; Lale and Ajayi, 2001; Minarro and Dapena, 2003; Gill and McSorley, 2010; Summers et al., 2010).

\section{Effects on Soil Chemistry and Microbial Ecosystem}

Generally, the highest temperature (more than $50^{\circ} \mathrm{C}$ ) can be achieved during daytime only in the upper $5 \mathrm{~cm}$ of soil. At lower depth $(10-15 \mathrm{~cm})$ soil temperature may pass $40^{\circ} \mathrm{C}$ in warm environment and during summer, and more than $35^{\circ} \mathrm{C}$ can be achieved up to $30 \mathrm{~cm}$ depth (Stapleton, 1997). However, the effect of energy emitted by sun on soil temperature is strongly dependent to climate and weather.

Plasticulture enhanced the availability of useful constituents (potassium, nitrogen, magnesium, and manganese) in easier to assimilate compounds that can increase pathogen tolerance, and eventually increase the yield of crops by altering chemistry of soil and its physical characteristics through increased breakdown of organic material (Ahmad et al., 1996; Elmore et al., 1997; Chellemi and Mirusso, 2006). Nitrogen transformations (nitrification and ammonification) were found to be greater in treated fields compared with non-solarized ones (Stevens et al., 1991), while integration of manure with soil solarization found to be greatly increased the $\mathrm{C}, \mathrm{N}$, and $\mathrm{P}$ pools. This integration could be used as key plan to defend farming lands from soil mistreatment and to enhance pest control while maintaining soil fertility (Gelsomino et al., 2006). Plasticulture helped at increasing the concentration of $\mathrm{NO}_{3}{ }^{-}$ and $\mathrm{NH}_{4}^{+}$up to six times compared to non-solarized soils. It also increased the $\mathrm{P}, \mathrm{Ca}^{+2}, \mathrm{Mg}^{+2}$, and electrical conductivity, which was linked to the greater quantity of ions released following decomposition and mineralization of organic matter (Chen and Katan, 1980) and increased yield of many crops as observed in solarized plots (Stapleton et al., 1985).

Most of the soil microorganisms are beneficial and enzymatic activities are considered as biosensors of soil health (Aon and Colaneri, 2001; Aon et al., 2001; Poll et al., 2006; Velmourougane et al., 2013) thus impact of soil treatment on microbial ecosystem is crucial. Effectiveness of soil solarization was also related to effect of treatment on availability of chemical compounds originated from degradation of mesophilic microorganisms. This increment of nutrients can lead to an increased growth of benefic antagonists of plant pathogens that were commonly reported in treated soils (Stapleton and DeVay, 1995; Weller et al., 2002). Desirable effects are also associated with shifts in soil microflora caused by reduced pressure on soil microbiota by microorganism-grazers which are stressed by plasticulture (Gupta and Yeates, 1997). Generally, heating treatment caused significant changes in biodiversity of soil microflora (D'Addabbo et al., 2010), while studies on the fungi and bacteria communities of plasticulture-treated soils showed lower cumulative carbon metabolic activities than untreated ones (Luvisi et al., 2015). Thus, plasticulture causes shifts in microflora composition which can consume carbon substrates at lower efficiency as control. The measurement of carbon source utilization richness (which reflect different microorganism metabolism) and the Shannon's index of carbon source utilization (related to functional diversity) were also slightly affected by solarization (Luvisi et al., 2015). Furthermore, soil composition may also interfere with soil biota during solarization due to decomposition of organic material that can produce fizzy chemicals poisonous to microorganisms in soil (Gamliel et al., 2000). Contrasting reports (positive or negative shifts) in soil bacteria were reported, with Bacillus species as predominant surviving after soil solarization treatments (D'Addabbo et al., 2010), while reduction of soil rhizobia was generally followed by quick recover (Linke et al., 1991).

The integration of soil biofumigation with plasticulture (biosolarization) is considered a sustainable option for crop protection (Mauromicale et al., 2010; Domínguez et al., 2014), and biofumigation may also increase growth of beneficial microorganism (Camprubí et al., 2007). Further study conducted in southern Italy, documented that integration of soil solarization with organic amendments keep microbiota and soil enzymatic properties protected from deleterious heating effects (Scopa and Dumontet, 2007). 


\section{APPLICATIONS OF SOIL SOLARIZATION IN INDIA}

An incredible amount of work is being done on solarization throughout the world with humid and hot climate. Compared to this, in India, less work is being done so far, and if it is done, it did not get in the limelight. Most of the work done on soil solarization in India did not get published online. Our literature survey included articles, books, and conference papers (retrieved from Scopus database, Research gate, and Google Scholar). We also carried out interviews with Indian scientists and technicians who worked on soil solarization in India. Interviews were mainly done by email survey, collecting stored data, and personal communications about local applications of soil solarization. In the following section of this review, the research work done in various states of India is discussed. These states fall under the humid, moist sub-humid, dry sub-humid, semi-arid, and arid climatic zones of India (Table 1) based on administrative districts as given by Raju et al. (2013). Air and soil solarization temperatures attained at different sites in these states are shown in Table 2.

\section{Humid Climate Zone}

Manipur and parts of Karnataka states fall into this climate zone. The main plants cultivated in this zone are rice, maize, jowar (Sorghum spp.), ragi, pulses [tur (Cajanus cajan), and gram], and other oilseed crops. In Manipur, soil solarization was more efficient in managing pigeon pea wilt, caused by Fusarium udum Butler compared to organic amendments (FYM or poultry manure) or intercropping with maize (Devi and Chhetry, 2013). In Southern peninsular India, Karegowda et al. (2008) found soil solarization alone is not giving a better cost-benefit ratio in reducing the incidence of damping-off disease (Pythium aphanidermatum) of FCV tobacco. The economic returns improve when solarization combines with twice drenching of soil

TABLE 1 | Classification of climate zones of India and locations (state and city) in which soil solarization trials were carried out.

\begin{tabular}{ll}
\hline Climate zone & State (city) \\
\hline Humid & Karnataka (Shimoga) \\
& Manipur (Manipur) \\
Moist sub-humid & Himachal Pradesh (Shimla, Solan) \\
& Kerala (Trivandrum) \\
& Uttarakhand (Haldwani, Pantnagar) \\
& West Bengal (Burdwan) \\
Dry sub-humid & Madhya Pradesh (Akola, Gwalior, Jabalpur) \\
Semi-arid & Delhi (Delhi) \\
& Karnataka (Bangalore) \\
& Gujarat (Gandhinagar) \\
& Punjab (Abohar, Jalandhar, Ludhiana) \\
& Tamil Nadu (Chidambaram) \\
& Telangana (Hyderabad) \\
& Uttar Pradesh (Allahabad, Lucknow) \\
Arid & Rajasthan (Jodhpur)
\end{tabular}

with cow urine and a spray of Ridomil MZ 72 (0.2\%). Excessive rains in this climate zone hamper the exclusive use of solarization, but it can be beneficial when used in conjunction with other management practices. Not many known studies were conducted in humid zone, but soil solarization could be used as a potential pest management option for managing pests of chili, cardamom, tea, coconut, and coffee.

\section{Moist Sub-humid Zone}

Uttarakhand, Himachal Pradesh, West Bengal, and Kerala states come under moist sub-humid climatic zone.

\section{Uttarakhand}

It is mainly a hilly state located in the northwestern part of India. Cultivable land constitutes only $20 \%$ area of the state. Rice, coarse cereals, wheat, groundnuts, soybean, pulses, and oilseeds are common crops cultivated in Uttarakhand. Few solarization studies were carried out in Nainital and Pantnagar districts (as given below) on soybean and sorghum crops and beneficial results were found.

- Haldwani (Nainital district). With solarized soil attaining temperatures of $41^{\circ} \mathrm{C}$ at $6 \mathrm{~cm}$ soil depth, Dubey et al. (2009) reported a decline in the incidence of charcoal rot of soybean due to Macrophomina phaseolina infection from $85 \%$ in the unsolarized soil to $70 \%$ in solarized soil. Combining soil solarization with neem powder cake further caused reduction of rot disease to $60 \%$ with the additional benefits of increased seedling growth and biomass.

- Pantnagar. Solarization from mid-May to mid-June with $25 \mu \mathrm{m}$ transparent polyethylene sheets rises of $10^{\circ} \mathrm{C}$ the average maximum temperature of the soil at $5 \mathrm{~cm}$ soil depth over the non-solarized soil. The temperatures higher than 45 and $50^{\circ} \mathrm{C}$ were measured at 5 and $10 \mathrm{~cm}$ depths for the most duration of soil solarization (Table 2). Plasticulture alone or integration with Trichoderma harzianum (TH 43 and $\mathrm{TH}$ 39) and Pseudomonas fluorescens (PSF 27) reduced disease severity of anthracnose of sorghum, increased plant height and collar diameter (Singh, 2008).

\section{Himachal Pradesh}

Himachal Pradesh is also a hilly state and lies on the western side of Uttarakhand. Its climate is also similar to Uttarakhand with a same temperature range in the months of May to June. Most cultivated plants grown in Himachal are wheat, barley, maize, rice, with apple as the main cash crop. Solarization studies in Himachal mainly focused on fruit crops and found effective to manage many kinds of plant diseases.

- Solan. Solan have moderate climate during summer with maximum daily temperatures $21-37^{\circ} \mathrm{C}$ with little cloud cover. Gupta and Khosla (2007) observed that soil temperature increased by $13-14,4-5$, and $2-3^{\circ} \mathrm{C}$ at soil depth of 8,15 , and $30 \mathrm{~cm}$, respectively, when irrigated clay loam soil was covered with $25 \mu \mathrm{m}$ thick transparent plastic film for 3 months from April to June as compared to temperature achieved in non-solarized soil. The average temperatures increase of $19-57 \%$ at $15-8 \mathrm{~cm}$ soil depths 
TABLE 2 | Soil solarization temperatures achieved in different climate zones of India.

\begin{tabular}{|c|c|c|c|c|c|c|c|}
\hline \multirow[t]{2}{*}{ State } & \multirow[t]{2}{*}{ Soil* } & \multirow[t]{2}{*}{$\mathrm{PE}(\mu \mathrm{m})^{* *}$} & \multicolumn{2}{|c|}{ Solarized soil } & \multicolumn{2}{|c|}{ Control soils } & \multirow[t]{2}{*}{ Reference } \\
\hline & & & $\operatorname{Max}^{* * *}$ & Min & Max & Min & \\
\hline \multicolumn{8}{|l|}{ Moist sub-humid } \\
\hline Himachal Pradesh & $\mathrm{CL}$ & 25 & 49 & 25 & 37 & 21 & Gupta and Khosla, 2007 \\
\hline Himachal Pradesh & LS & 25 & 47 & 18 & 37 & 15 & Sharma et al., 2005 \\
\hline Uttarakhand & - & 25 & 55 & - & 44 & - & Singh, 2008 \\
\hline Kerala & - & 50 & 42 & - & 36 & - & Nair et al., 1990 \\
\hline West Bengal & $\mathrm{CL}$ & 25 & 48 & 39 & 39 & 30 & Chakraborty et al., 2009 \\
\hline \multicolumn{8}{|l|}{ Dry sub-humid } \\
\hline Madhya Pradesh & LS & 110 & 52 & - & 46 & - & Verma et al., 2010 \\
\hline \multicolumn{8}{|l|}{ Semi-arid } \\
\hline Delhi & LS & 100 & 48 & 34 & 40 & 32 & Kumar et al., 1993 \\
\hline Uttar Pradesh & - & 47 & 54 & - & 45 & - & Dwivedi, 1998 \\
\hline Telangana & V & 100 & 48 & 38 & 39 & 33 & Chauhan et al., 1988 \\
\hline Tamil Nadu & $\mathrm{CL}$ & 200 & 46 & - & 28 & - & Jayaraj and Radhakrishnan, 2008 \\
\hline \multicolumn{8}{|l|}{ Arid } \\
\hline Rajasthan & LS & 50 & 51 & 45 & 53 & 49 & Lodha et al., 1997 \\
\hline
\end{tabular}

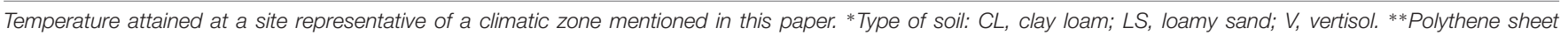
thickness. ${ }^{* * *}$ Temperature $\left({ }^{\circ} \mathrm{C}\right)$ at $10 \mathrm{~cm}$ depth.

in solarized plots of cherry. It reduced the crown gall (A. tumefaciens) incidence in cherry rootstock colts from $45 \%$ in non-solarized to $15 \%$ in solarized plots. The effect of solarization in non-irrigated plots was less effective (27\%). Further integration of solarization with Bacillus subtilis BCA6 reduced crown gall incidence to $11 \%$. Raj and Sharma (2005) found that 40 days of plasticulture with transparent plastic film (25 $\mu \mathrm{m}$ thickness) was effective for controlling collar and root rot of strawberry which was caused by Sclerotium rolfsii during June to July. The treatment caused absolute death of sclerotia of the pathogen at $7 \mathrm{~cm}$ soil depth, but the effectiveness of plasticulture was lower when soil depth increase; plasticulture for shorter time (40 days) caused only 80 and $73 \%$ mortality of sclerotia of S. rolfsii at $15 \mathrm{~cm}$ depth. The effectiveness of solarization was enhanced with root dipping of strawberry runners in association of chemical treatments with carbendazim $12 \%$ and mancozeb $63 \%(0.2 \%)$ or thiophanate methyl $(0.1 \%)$; in this case, cultivation in treated soils resulting in no infected plant. Raj and Sharma (2009) found inoculation of apple with AMUHF1 isolate of vesicular-arbuscular mycorrhiza and AZUHF1 isolate of Azotobacter chroococcum, and followed by cultivation in treated soil with clear polyethylene mulch of $25 \mu \mathrm{m}$ thickness for 40 days in summer months to be effective. White root rot (Dematophora necatrix) was totally controlled in treated plots compared to $34-35 \%$ of incidence in untreated ones. Root and shoot length of the apple saplings was higher in solarized plots compared with sterilized plots. In mid-hill rainfed weather conditions of Solan, Sharma et al. (2011a) reported solarization of clay loam soil with $100 \mu \mathrm{m}$ thick, UV-stabilized, transparent polyethylene sheets rise the maximum temperature to more than $48^{\circ} \mathrm{C}$ while the minimum temperature exceed $29^{\circ} \mathrm{C}$ up to $25 \mathrm{~cm}$ depth in warmer months. With black polyethylene mulch, the maximum average soil temperature was $40^{\circ} \mathrm{C}$ in treated soil. They found that combining rhizosphere soil inoculation with arbuscular mycorrhizal (AM) fungi and plasticulture using black plastic mulching was the efficient method for citrus nursery protection under midhill rainfed weather conditions of the State. The AM fungi especially Glomus fasciculatum (Thaxter sensu Gerdemann) and A. chroococcum (especially AZ1 strain) significantly increased plant growth, caused beneficial shifts in microflora composition of the rhizosphere and increase content of essential elements such as nitrogen, phosphorous, potassium, and zinc in leaf compared with other soil treatments. Sharma et al. (2011b) also observed similar technique to be beneficial for apple nursery too.

- Shimla. Sharma et al. (2005) found that long-duration plasticulture treatments during May to June were effective for management of soil-borne pathogens in temperate areas. In their study, soil solarization was conducted for $2,4,6,8$, 10, and 12 weeks period in April to June, using polyethylene sheets of $25 \mu \mathrm{m}$ thickness. Plasticulture was most effective during May but satisfactory control of pathogens was also obtained in June, while treatments in April lead to worse results. Twelve weeks of plasticulture in fruit nurseries caused the highest decrease in population of most soil-borne microorganisms, while survival up to $40 \%$ of propagules of D. necatrix, the agent of white root rot disease, was observed at $15 \mathrm{~cm}$ depth.

\section{West Bengal}

West Bengal lies in the eastern part of the country with the Bay of Bengal lining its southern border. Rice, wheat, jute, potato, and sugarcane are the most common grown crops in this state. This state is big supplier of potato (90\%) and jute (66\%) for India. The other crops include vegetables, maize, barley, oil seeds, and pulses. Maximum and minimum air temperature of 33 and $27^{\circ} \mathrm{C}$ was reported in West Bengal during the months of May to 
June. Major solarization work is done on vegetables and jute with promising results.

In Burdwan, Chakraborty et al. (2009) found the provision of additional $50 \mu \mathrm{m}$ polyethylene sheet for $2 \mathrm{~h}$ at peak hot time of the mid-May to mid-June over and above the transparent polyethylene sheet (25 $\mu \mathrm{m}$ thickness) further raised the soil temperature from 39 to $48^{\circ} \mathrm{C}$ in solarized clay loam type soil (Table 2). In untreated soil, it can change from 30 to $39^{\circ} \mathrm{C}$ up to $10 \mathrm{~cm}$ depth. Soil covered with polyethylene sheet markedly got temperatures of $46^{\circ} \mathrm{C}$ (average), while the non-solarized treatments differed almost $9^{\circ} \mathrm{C}$ lower. They observed 71 and $83 \%$ reduction in fusarial wilt ( $F$. solani) of eggplant in solarized plots alone, in two sequential growing seasons. Further combining soil solarization with T. harzianum or Trichoderma viride, neem and bavistin provided $100 \%$ inhibition of fusarial wilt of eggplant.

Transparent and black polyethylene sheets of 200-400 gauge thickness raised the soil temperature up to $54^{\circ} \mathrm{C}$ in $0-5 \mathrm{~cm}$ soil depth compared to $38-40^{\circ} \mathrm{C}$ in control bare plots. Sprouted grass, broad-leaved weeds, and sedges were killed in jute crop, and weed emergence was reduced by $45-78 \%$. Soil solarization can be practiced by growers provided that the cost of polyethylene sheets is low, and its safe disposal is easy (Ghorai, 2007).

\section{Kerala}

This Indian state famous as "Spice Garden of India" lines the western side of South India. Agricultural sector is mainly focused on coconut, tea, coffee, cashew, and spices. Few solarization studies were conducted and more work can be done in future to sustain the ecology of this state. In trial test at Trivandrum, root nodulation increased by $105 \%$, infection caused by mycorrhizal fungi rise by $20 \%$ and yield was also increased by $24 \%$ compared to unsolarized soil (Nair et al., 1990). Transparent LDPE (lowdensity polyethylene sheets) of 50 gauge thicknesses was used as soil cover for 30 days. It reduced the weed growth and increased rice yield in tests carried out in Bhubaneswar (Orissa). Higher yield was documented in transparent sheets of 200-400 $\mu \mathrm{m}$ thickness for 1 month, followed by soil coverage with black sheets. The period of soil cover with plastic sheets should be decided based on soil and air temperatures, and solar radiations to kill soil pests and weeds (Khan et al., 2003).

\section{Dry Sub-humid Zone Madhya Pradesh}

This state is sited in the central part of India. The weather of Madhya Pradesh is classified as subtropical; springs are generally hot and dry, while consecutive monsoon rains characterized the summers. Winters are cool and relatively dry, with rainfall of about 54 inches. More than 30\% area of this state is under forests. Cereals, pulses, and oilseeds are widely cultivated. In few districts of this state, farming of cotton and sugarcane is carried out. Loamy sand soil is the most common soil type reported in this state.

- Jabalpur. Jabalpur is located at an elevation of 415 masl with average air temperature range between 41 and $21^{\circ} \mathrm{C}$ during April to June. Solar heating of nursery seedbeds with the top soil consisting of a mixture of loam, sand, and farm yard manure was done for 1 month, with transparent sheet of $0.11 \mathrm{~mm}$ of thickness. Maximum temperatures achieved at $5 \mathrm{~cm}$ depth exceed $60^{\circ} \mathrm{C}$ with a mean difference of $10^{\circ} \mathrm{C}$ above control. The highest difference of temperature was $9^{\circ} \mathrm{C}$ whereas the minimum was $4^{\circ} \mathrm{C}$ with average difference of $6^{\circ} \mathrm{C}$ at $10 \mathrm{~cm}$ depth (Table 2). This enabled complete elimination of the soil inoculum of F. solani, F. oxysporum, Penicillium, and Rhizopus from upper 0-10 cm depth. The population of Aspergillus, Trichoderma, nematodes, AM fungi and bacteria decreased more in $0-5 \mathrm{~cm}$ soil depth and to a lesser extent in 5-10 cm depth. Solar heating also resulted in increased vegetative growth of seedlings of Gmelina arborea and Tectona grandis compared to the non-solarized control (Verma et al., 2010).

- Akola. Field studies were conducted on Citrus at Akola, at 5 and $15 \mathrm{~cm}$ soil depths. It was documented a temperature gain of $9-11^{\circ} \mathrm{C}$ at $5 \mathrm{~cm}$ depth, causing a control of Phytophthora spp. inoculum from 38.2 to $2.0 \mathrm{cfu}$ (Gade and Giri, 2005).

- Gwalior. Field experiment was conducted with various agronomical and physical weeds control methods, plasticulture (for 45 days), green manuring, and mulching by green biomass. The worse control of wild plants was obtained in non-solarized plots, followed by practices such as green manuring, stale seed bed, mulching, and deep plowing. Soils treated with plasticulture achieved the better results, resulting as one of the best chemical free weed management method (Arora and Tomar, 2012).

\section{Semi-arid Zone Uttar Pradesh}

This state is in north-central region of India. The average maximum and minimum air temperature in the month of May to June are 40 and $25^{\circ} \mathrm{C}$, respectively. Cereals, oilseeds, pulses, and potatoes are the most cultivated plants and sugarcane is the main cash crop throughout the state.

- Allahabad. Soil solarization with $40 \mu \mathrm{m}$ thick transparent polyethylene sheets during May to June 2012 at Allahabad increased average maximum soil temperature than unmulched one by more than $15^{\circ} \mathrm{C}$ up to $10 \mathrm{~cm}$ depths (Kamaluddeen and Simon, 2013).

- Lucknow. Plasticulture performed for 21 days in June raised the temperature of solarized plot by 8,7 , and $14 \%$ compared to unsolarized plot at 5, 10, and $15 \mathrm{~cm}$, respectively. Plasticulture caused significant detrimental effects in the population of F. oxysporum f.sp. ciceris and F. udum, the agents of wilt in chickpea and pigeon pea, respectively. After 21 days of solarization, the population of both pathogens was reduced by more than $72 \%$ at $5 \mathrm{~cm}$, by $>60 \%$ at $10 \mathrm{~cm}$ and by $>53 \%$ at $15 \mathrm{~cm}$ soil depths. The population of M. incognita was also reduced significantly by 58\% (Shukla and Dwivedi, 2011). In another solarization study, the upper soil layer $(0-8 \mathrm{~cm})$ reached $54^{\circ} \mathrm{C}$, while no more than $45^{\circ} \mathrm{C}$ were recorded in untreated soil (Table 2). The inoculum of Colletotrichum falcatum and Fusarium moniliforme, two widespread pathogens of sugarcane, was almost eliminated up to $24 \mathrm{~cm}$ soil depth. Dwivedi (1998) also reported 
complete elimination of propagules of Rhizoctonia solani and S. rolfsii at $24 \mathrm{~cm}$ of soil depth. Dwivedi (1991b), Dwivedi R. (1993), Dwivedi S.K. (1993) reported that soil solarization (depth of $16 \mathrm{~cm}$ ) reduced the inoculum of many species of Fusarium and $R$. solani related to wilt diseases of guava. Similar results are also reported the inhibition and eradication of charcoal rot pathogen (Dwivedi and Dubey, 1987; Dwivedi, 1991a) and tomato wilt pathogen (Dwivedi, 1991b).

\section{Punjab}

It is a northwestern state, and a major food bowl of India. Wheat and rice are the main cereal crops followed by cotton and citrus. Potato, sugarcane, maize, pulses, and vegetables are also cultivated. Temperature in summers exceeds $40^{\circ} \mathrm{C}$ with low of $26^{\circ} \mathrm{C}$. Solarization has been tried on potato and high-valued vegetable crops in protected cultivation.

- Abohar. A field experiment was conducted in Abohar, Punjab and it was reported that transparent plastic sheets for 1 month showed good control of pathogens, and it drastically increased (more than 90\%) the soybean yield (Singh, 2006).

- Jalandhar. Soil solarization reduced major annual weed Coronopus didymus and total number of weeds, but had no effect on the population of $C$. rotundus on true potato seeds. Increased yield showed that soil solarization involved elevation of plantlets in treated nursery beds and their movement to the untreated plots is advantageous for growing potato plants (Kumar and Sharma, 2005). Soil beds for potato growth were covered with $50 \mu \mathrm{m}$ LDPE sheets for 4 weeks in June at Jalandhar. Plastic films rise soil temperature up to $53^{\circ} \mathrm{C}$ at ground level, 51,44 , and $39^{\circ} \mathrm{C}$ at 5,10 , and $15 \mathrm{~cm}$ depth, increasing soil temperature by $11,9,6$, and $4^{\circ} \mathrm{C}$ at respective soil depths in unsolarized control plots. This led to increased yield from micro and mini-tuber potato crop (Singh et al., 2009). A similar trial was carried out to estimate the quality and quantity of potato seed. The weed populations were reduced by $95 \%$ and its fresh weight by $97 \%$. Nutrients availability was increased by 18,63 , and $27 \%$ at planting and 16,22 , and $15 \%$ at harvesting, respectively. Plasticulture also increase the yield of micro-tuber (32\% of increase) and mini-tuber (15\% of increase) compared to untreated soil (Singh et al., 2012).

- Ludhiana. Solanaceous and cucurbitaceous vegetable plants are cultivated in net houses in the Punjab state of India. The severe attack of soil-borne pathogens such as sclerotinia wilt (Sclerotinia sclerotiorum) and root-knot nematode was detected during a disease survey of solanaceous and cucurbitaceous vegetable crops in greenhouses in many locations in the Punjab state of India during the cold seasons (Aujla et al., 2011). Application of $50 \mu \mathrm{m}$ LDPE sheets both on the soil surface and roof top of the net house enabled the average minimum temperature of wet, sandy loam soil to remain above $41^{\circ} \mathrm{C}$ from 5 to $40 \mathrm{~cm}$ depth for more than $288 \mathrm{~h}$ in the last fortnight of 30-day solarization period in the months of May to June (Iqbal Aujla, unpublished data).

\section{New Delhi}

New Delhi is a capital state of India and it has a characteristic semi-arid to arid climate with average temperature range of 26$39^{\circ} \mathrm{C}$ in May to June. Soil type is sandy loam. Wheat, paddy, jawar, and bajra are the main crops grown in Delhi, along with vegetables includes cauliflower, cabbage, carrot, spinach, mustard (leaves), okra, and tomato. It has been hub of solarization studies in India since 1990s for control of soil-borne pathogens and wild plants, but the technology spread is not widespread. Being the administrative center of Indian agriculture, it needs to put more concerted efforts in spread of solarization technology in India.

At New Delhi, mulching of sandy loam soil for 3 weeks with transparent polyethylene sheets of $60 \mu \mathrm{m}$ thickness increased the temperature by $16 \%$. Solarization (when temperature exceeded $40^{\circ} \mathrm{C}$ ) reduced the population densities of rootknot, and reniform nematode better than non-mulched fallow in eggplant seedlings. However, amendment of soil with farmyard manure or mahua (Madhuca indica) cake before polyethylene mulching did not enhance the solarization (Gaur and Dhingra, 1991). Soil solarization proved superior in terms of weed control (C. dactylon) and efficiency in soybeanwheat farming system. Other practices like mulching using wheat straw and repeated cultivation with irrigation were closely effective as soil solarization (Das and Yaduraju, 2008). Kumar et al. (1993) reported that polyethylene mulching for about a month reduced plant-parasitic nematodes (Tylenchus spp., Heterodera spp., Xiphinema spp., Hoplolaimus spp., Pratylenchus spp., and Rotylenchus spp.) populations by $90 \%$ and, populations of saprophytic nematodes by $60 \%$. But, the nematode returned to similar pre-solarization levels after 70 days.

In summers, soil solarization followed by glyphosate and in rainy season imazethapyr in soybean controlled $C$. rotundus better and increase soybean-wheat yield compared to different control methods in both seasons (Kumar et al., 2012a,b). During 3-year trial, it was found that soil solarization followed by glyphosate $(1.0 \mathrm{~kg} / \mathrm{ha})$ reduced the dry weight and weed density by $85 \%$ in soybean and $65 \%$ in wheat (Triticum spp.). Soybean seed yield was $62 \%$, and wheat yield was $28 \%$ higher compared with other practices such as summer plowing. The soil solarization followed by glyphosate being superior in weed control and productivity proved to be a beneficial practice in soybean-wheat system, but due to its high cost it was not as economical as the smother crop (cowpea) (Kumar and Das, 2008). Solarization mulching for 1 month decreased the seed emergence of weeds Dactyloctenium aegyptium, A. racemosa, C. rotundus, and Trianthema monogyna by over $90 \%$ in soybean. Sixteen-day of mulching also decreased the wild plants emergence, but it was less effective than 32-day mulching treatment. Plasticulture also increase the soybean growth, while seed yield was also affected (78\% of increase) following soil solarization (Kumar et al., 1993).

Plasticulture with polyethylene film significantly increased $\mathrm{NO}_{3}{ }^{-}$and $\mathrm{NH}_{4}{ }^{+}$nutrients in comparison with untreated soils. Thirty days of soil solarization strongly control seeds of many 
wild plants such as Phalaris minor and Avena fatua, whereas the treatment was poorly effective against Asphodelus tenuifolius and T. monogyna. Such different effect on weeds can be esteemed calculating the ratio of seed germination in solarized condition on seed germination in untreated soil. The index, named solarization reduction index, esteemed as easier to control plants with low value (Arora and Yaduraju, 1998).

\section{Tamil Nadu}

Tamil Nadu is sited in the southernmost part of Indian Peninsula. Paddy and pulses are two main crops grown in this state, but big production of turmeric, banana, mango, coconut, groundnut, and natural rubber are also recorded. It is also the third largest sapota, coffee, tea, and sugarcane producer. The production of sugarcane is unbeaten in Tamil Nadu. In the central part of the state, average temperatures range from 23 to $37^{\circ} \mathrm{C}$ during the months of May to June. The average temperature during the months of May to June range from 23 to $37^{\circ} \mathrm{C}$. There is lot of scope of soil solarization in this state based on temperatures and crop type.

UV-stabilized transparent polyethylene sheets of $200 \mu \mathrm{m}$ thickness were laid on clay-loam soil (late spring) at Chidambaram Taluk. At soil depths of 10 and $20 \mathrm{~cm}$, the temperature raised by 65 and 50\% respectively, compared to untreated soils. Soil solarization integration with other management option was found effective for pest control (Gill and McSorley, 2010). Significant reduction (up to 55\%) in rhizosphere population of Pythium spp. causing tomato damping-off was observed in treated soils and which was further reduced to $>82 \%$ by application of biocontrol agents (BCAs), T. harzianum and $P$. fluorescens. Disease incidence was also reduced by $>83 \%$ in combination with soil solarization and BCAs (Jayaraj and Radhakrishnan, 2008).

Plastic polyethylene mulches were found effective in minimizing weed infestations and increasing yield of groundnut pods. However, the net benefit: cost ratio did not differ between treatments (soil solarization and pre-planting addition of herbicides in flat-bed system) (Subrahmaniyan et al., 2002).

Hyderabad is located in southern part of Telangana state in peninsular India. Hyderabad has a tropical wet and dry climate. Most of the annual rainfall is received in June to September months. Maximum and minimum air temperature of 39 and $24^{\circ} \mathrm{C}$ are reported for the months of May to June. Cotton, paddy, maize, and groundnut are the major plants grown in this area and vertisol is the common soil type in this state. Solarization studies were conducted mainly on pigeon pea and chick pea at ICRISAT located in this city in 1990s, still there is lot of scope to work on other corps in this state.

Soil was covered with transparent polyethylene sheets of $100 \mu \mathrm{m}$ thickness for 2 months during spring in 2 -year trials at Patancheru. Soil temperature increased about $10^{\circ} \mathrm{C}$ at soil depth of $5 \mathrm{~cm}$. The temperatures higher than $40^{\circ} \mathrm{C}$ is potentially deadly for most pathogens, and this value was frequently noticed at 5-10 cm depths of solarized soils, while such high-temperature ranges were fewer in non-solarized control treatment (Chauhan et al., 1988). Sharma and Nene (1990) found that plasticulture also reduced the pre-plant nematode population densities.
Transparent polyethylene sheets of $100 \mu \mathrm{m}$ thickness, for 1.5 month during the summer months reduced the nematodes (Helicotylenchus retusus, Heterodera cajani, Pratylenchus sp., $R$. reniformis, and Tylenchorhynchus sp.) populations which are pathogens for chickpea and pigeon pea crops. Decrease in population density (93\%) was observed for eggs and juveniles of $H$. cajani, while higher values were recorded for Pratylenchus spp., $H$. retusus, and $R$. reniformis $(98,99$, and $100 \%$, respectively) by $6-10^{\circ} \mathrm{C}$ increase in soil temperatures in 0 - to $20-\mathrm{cm}$ soil depth. Irrigation of soil before covering with polyethylene sheets improved the soil solarization effectiveness and reduced the $H$. cajani population. Soil solarization greatly increased seed yield and dry matter of pigeon pea. The residual effects of solarization on seed yield and total dry matter were not significant.

A further study was conducted at Patancheru, for a week in June. In tropics and sub-tropics, bruchids (Callosobruchus spp.) are main post-harvest threat of legumes plants including pigeon pea cultivar and cause significant economic losses. During the period of experimentation, solar irradiance elevated the temperature to $65^{\circ} \mathrm{C}$ in seed bags. No damage on bruchids was observed in seeds treated with plasticulture after 41 weeks of post-harvest conservation, and no detrimental effect was observed on germination. Conversely, damage of bruchids involved up to $91 \%$ of seeds, and reduction of germination ( $42 \%$ of decrease) was observed. Growers in these regions should consider plasticulture as an environmentally safe and cost-saving method to protect pigeon pea seeds (Chauhan and Ghaffar, 2002). Chauhan et al. (1988) reported that Fusarium wilt disease was effectively controlled in the susceptible genotypes of pigeon pea and chickpea. However, N-fixation and nodulation were adversely affected due to decline in population of Rhizobium with solarization. Due to compensatory effect of increased soil nitrate, plant development and production per hectare were not adversely affected. Even in wilt-resistant genotypes of both pigeon pea and chickpea crops, mainly of pigeon pea, there was a significant increase in yield other than disease control.

\section{Gujarat}

Gujarat, a home-state of Mahatma Gandhi, is on the western coast of India. Main cultivated plants of this state are groundnut, dates, cotton, and sugarcane. Cereals, pulses, oilseeds, and cotton are widely cultivated; fruit trees and vegetables also have significant percent in cultivated crops. It is also a major producer of milk and milk products. International Food Policy Research Institute reported the annual growth rate of $28 \%$ between 2000 and 2008. Winters are dry, mild with an average daytime temperature of $29^{\circ} \mathrm{C}$ and a nighttime temperature of $12^{\circ} \mathrm{C}$. Summers are scorching and dry with a day high and low above 38 and $30^{\circ} \mathrm{C}$, respectively.

Patel et al. (1991) found that tarping the beds with clear LDPE film (400 gauge) for 2 months during hot summer months reduced root-knot disease by $58 \%$ in Gujarat. Patel et al. (1995) found tarping the beds with clear LDPE plastic of 100 gauge $(25 \mu \mathrm{m})$ for 15 days during summer to be as effective as 400 gauge $(100 \mu \mathrm{m})$ for 60 days in getting higher number of bidi tobacco transplants and incremental cost-benefit ratio. 


\section{Karnataka}

This state is in south western region of India. Climate is subtropical, with summer temperatures reaching $40^{\circ} \mathrm{C}$ in the interiors of the state. Most solarization studies have been conducted on groundnut, French beans, and tomatoes; still there is lot of scope of solarization in other crops.

A combination of solarization and hand weeding was effective for decreasing weeds and increasing groundnut pod yield compared to other treatments which includes solarization along, hand weeding and Alachlor chemical (Soumya et al., 2004). The maximum weed reduction was obtained by transparent plastic film of $0.05 \mathrm{~mm}$ thickness for 60 days in wet soils, and maximum yield (28.75 q/ha) was also recorded in groundnut (Biradar and Hosamani, 1997).

The extent of rise in temperature ranged from 8 to $12^{\circ} \mathrm{C}$ at $5 \mathrm{~cm}$ and 7.2 to $11.6^{\circ} \mathrm{C}$ at $10 \mathrm{~cm}$ of soil depth by transparent polyethylene sheets of $0.5 \mathrm{~mm}$ thickness in April. In tomatoes, weed control efficiency was maintained till harvest and it was above $80 \%$ and, and the highest yield of $21.6 \mathrm{t} /$ ha was achieved (Kumar et al., 2001). The decrease in weed counts due to integration of glyricide and soil solarization was $77 \%$ at 3 months after sowing and $74 \%$ at harvest in groundnut, whereas weed reduction was $55 \%$ at 55 days after sowing in French bean. Similarly, integrated treatment of soil solarization and crop residues increased the yield and other yield components (Mudalagiriyappa Nanjappa and Ramachandrappa, 2001).

\section{Arid Zone}

\section{Rajasthan}

With biggest desert of India located in this state, it has a typical arid climate with average day high of $41^{\circ} \mathrm{C}$. Uncovered soil temperature frequently reaches deadly ranges (up to $60^{\circ} \mathrm{C}$ ) (Israel and Lodha, 2004) during summer months. Lot of studies on soil solarization have been conducted in this region, in Jodhpur. Polyethylene mulching of irrigated and amended loamy sand soil raised the temperature to 57 and $50^{\circ} \mathrm{C}$ at $0-15$ and $16-30 \mathrm{~cm}$ soil depths, respectively (Lodha et al., 1997).

In a separate trial the soil temperature of unshaded amended pits achieved $41-45^{\circ} \mathrm{C}$, however, under shade temperature remained $6.5-11^{\circ} \mathrm{C}$ lower than corresponding unshaded pits. Maximal air temperatures ranged from 34.5 to $47.2^{\circ} \mathrm{C}$ during the corresponding period (Lodha et al., 2003). Same research team documented that temperature of amended soil increased by $2.5^{\circ} \mathrm{C}$ in non-amended soil $\left(42-51^{\circ} \mathrm{C}\right)$ at various soil depths. Integration of soil solarization and amendments also increased the soil temperatures compared to plasticulture $\left(1-5^{\circ} \mathrm{C}\right)$ or untreated soils $\left(3-13^{\circ} \mathrm{C}\right.$ ) (Israel et al., 2005). Israel et al. (2011) also observed that in mustard-amended polyethylene mulched plots temperatures may exceed $50^{\circ} \mathrm{C}$.

So even with the bare soil temperatures reaching at lethal ranges of $50-60^{\circ} \mathrm{C}$ during summer months, Israel and Lodha (2004) found it to be ineffective for reducing the population of F. oxysporum f.sp. cumini (Foc) chlamydospores which causes wilt on cumin. One summer irrigation provided the soil moisture which affected the chlamydospores sensitivity to plasticulture (Katan et al., 1976; Lodha, 1995). Various studies demonstrated the weakening of pathogenic propagules by varying degrees of sub-lethal heat treatments (Freeman and Katan, 1988; Mawar and Lodha, 2009). Lodha and Solanki (1992) found that polyethylene sheets of $50 \mu \mathrm{m}$ thickness reduced sclerotia inoculum of M. phaseolina by $98 \%$ of sclerotia per gram of soil at $5 \mathrm{~cm}$ soil depth, but effects were milder at deeper soil layers. It also resulted in 30\% increase in seed yield of Guar crop.

Combining soil solarization with urea $(20 \mathrm{~kg}$ nitrogen/hectare) and farmyard manure (10 t/ha) control F. oxysporum f.sp. cumini, reducing propagules by more than $92 \%$ at topsoil layer. The effects on propagules decreased with increasing soil depth, but the reduction was still $74 \%$ in wet mulched and amended soil and $56 \%$ in dry mulched soil at $30 \mathrm{~cm}$ soil depth compared to non-solarized plots. Similarly, the sclerotial population of $M$. phaseolina was reduced by $85 \%$ in wet nitrogen manure solarized plots compared to $69 \%$ in dry solarized and $10 \%$ in non-solarized plots. Seed yield of the following cumin and guar crops were also increased significantly (Lodha, 1995).

Ninety days of dry soil sub-lethal heating was not effective in reducing viable propagules of $M$. phaseolina. But even one summer irrigation with and without sub-lethal heat can reduce the viable pathogen propagules by 43 and 34\%, respectively. They also found that amendment of irrigated soil with Brassica spp. give $60-72 \%$ reduction in viable pathogen propagules, but its effect gets further enhanced to $89-96 \%$ on combining with sub-lethal heating. Plastic mulching alone was on par with one summer irrigation of oil-cake amendment and mustard residues (Mawar and Lodha, 2002; Lodha et al., 2003; Israel et al., 2005). Similar results involving the use of natural heat only with mustard oil cake and irrigation have also been reported by Lodha et al. (1997).

Integration of residues of Indian mustard with one irrigation and without plasticulture caused a $70-80 \%$ of reduction of the population of F. oxysporum f.sp. cumini due to the effect of hot summers on soil temperature of amended irrigated, reaching more than $40^{\circ} \mathrm{C}$ at topsoil layer (Mawar and Lodha, 2002). Interesting results were obtained in terms of residual effect of soil solarization, because a high rate of control of wilt ( $60 \%$ of reduction) was observed in the following winter. The effectiveness of amendments was improved when soils were previously treated with plasticulture, due to thermal stress caused by the treatment to the pathogens (Lodha et al., 2003; Israel et al., 2005; Mawar and Lodha, 2009).

Reduction of incidence of $M$. phaseolina and $F$. oxysporum f.sp. cumini pathogen was achieved at topsoil layer as compared to deeper ones (Lodha et al., 1997; Israel et al., 2005). Based on these results, this group suggests the Brassica spp. residues are a user-friendly alternative choice to plastic mulches to control soil-borne pathogens in hot, arid regions. From another set of experiments, Israel et al. (2011) suggests that the use of residues produced by farming practices (i.e., obtained from Verbesina plants), integrated by irrigation during hot periods and in combination with prolonged heating in managing F. oxysporum f.sp. cumini. Bohra et al. (1996) observed as root rot incidence of jojoba seedlings caused by $F$. solani was $3 \%$ in solarized plots compared to $13 \%$ in non-solarized plots. They also reported complete eradication of viable propagules of fungi, 
Cylindrocarpon lichenicola at $20 \mathrm{~cm}$ soil depth in solarized plots and no root rot and more vigorous growth of jojoba seedlings till 4 months.

\section{WIDESPREAD OF SOIL SOLARIZATION IN INDIA: FROM TRIALS TO APPLICATIONS}

\section{Conventional vs. Novel Protection Methods: The Role of Political Commitment to Widespread Soil Solarization}

India is a Federal nation that embraces 29 states plus 7 union territories characterized by very different climatic conditions, food markets, and rural policies. In this review, we report findings of solarization trials carried out in 15 states, thus large parts of national territory was untested for potential application of this technique. Conventional treatment methods such as chemicals are easier to use and their effectiveness is less dependent to environmental factors than biological or agronomical methods. Thus introduction or widespread of novel chemicals among farmers generally rely in solid trust in this approach, particularly in areas in which multifunctional role of agriculture is not so widespread. In 2013, only $0.6 \%$ of farming territories are certified as organic production, although common polity states strongly encourage the use of low chemical input (Agarwal, 2014). Conversely, solarization successful strongly rely in proper technical executions and other factors difficult to control such as weather conditions, water disposal, and soil properties. Thus, just suggest uncommon pest control methods may lead to failed policy due to (a) lack of efficiency of method due to peculiar environmental conditions and (b) farmer's distrust in a mostly unknown practices. This latter option should be more common in underdeveloped productive areas of India, where farmers' propensity toward risk is limited. In fact, some consideration about potential widespread of soil solarization in India may be related to economic factors. Economic issues are not only related to final consumers, but also to investors and farmers. Growers' propension toward risk exposure was strike by food safety emergency and recession in late 2000s, increasing costs of agricultural products and foods (Maetz et al., 2011), causing negative effects on worldwide agriculture and, in particular, to Asiatic farming (Shane et al., 2009; FAO, 2010). In this contest, the use of low-investment crop protection technique such as solarization seems appropriated, thanks to limited need of mechanization and additional input than plastic films and water.

To popularize adoption of soil solarization in horticulture, the Indian government constituted the National Committee on Plasticulture Applications in Horticulture (NCPAH) and 22 Precision Farming Development Centres has been established in India to promote solarization by undertaking trials, workshops, and training programs in different agriculture climate zones of the country. Besides the predominant application of conventional protection methods, this kind of political commitment seems necessary to develop a systematic knowledge transfer to local producers, increasing confidence among farmers toward soil solarization.

\section{Perspective on Impact of Solarization on Food Production and Environment}

Beside exact method of production the changes in agriculture in the next years can cause significant effect on food security. Analysis of climate risks for crops indicates that South Asia is one of the regions most exposed to the adverse impact on many plants that are relevant to inhabitants exposed to food safety risks (Lobell et al., 2008). In South Asia, estimations of production impacts from climate change in 2030 indicate severe effects on crops that represent the baseline of the human diet in the area, such as rice, wheat, maize, groundnut, or millet (Lobell et al., 2008). Predictions of food demands in 2050 indicate the need of drastically increase the foodrelated yields worldwide, which results in a more than $2 \%$ of increase of rate of production per year (Pingali, 2006). Conversely, the production rates of the most widespread plants in the world (wheat, rice, maize, soybean) are positioned in the range of $0.9-1.6 \%$ of increase per year, thus the gap from the predicted needs in the next decades is not so easy to fill (Ray et al., 2013). In India the production of rice is increasing of just $1.0 \%$ per year, while increase in Indian wheat yield is set at $1.1 \%$ per year. These rates may be not sufficient for Indian development, leaving unaltered the yield per person (Ray et al., 2013). Could soil solarization represent one of the tools that can contribute to fill the yield gap in India? The environmental conditions of many Indian States indicate that plasticulture is an efficient techniques to protect plants and support production. This evaluation is also supported by experimental trials carried out in various States, suggesting how soil solarization could be applied beyond actual contests. Higher levels of soluble minerals nutrients and nitratenitrogen were found in solarized soil. Parasitic weed, broomrape (Orobanche spp.), and rainy and winter season annuals are adequately controlled by solarization. In Jabalpur (Madhya Pradesh), the yield increase of about $100-125 \%$ in onion, $50-55 \%$ in groundnut, 70-75\% in Sesamum, and 77-78\% in soybean have been observed using soil solarization (Success Story, Yadav, ICAR, New Delhi, India). These increments could drastically change food availability in India and whole South Asia in the next years if solarization will be widespread.

Environmental impact can assume a significant role in widespread of solarization in India, due to the rapid increase in agriculture-related pollution in the Indian subcontinent. Global interest in physical soil treatment methods is rising due to the progressive elimination of methyl bromide as main method to disinfect soils before cultivation (Luvisi et al., 2015) and soil solarization did not impact negatively with air and water pollution, the two major environmental Indian concerns. However, the disposal of plastic film needs to be carefully evaluated if solarization will be more widely applied in India. With regard to the acreage potentially interested by soil solarization in India (according to actual 
or perspective plant production), the amount of plastic waste could be enormous, while the carbon footprint for film production can also be highly impacting. In this perspective, the use of biodegradable films seems unavoidable, as well as the development of new ones. Further issue for Indian rural development may be linked to the Kyoto protocol, an international agreements which will drive a substantially reduction of fossil fuels usage to appease the negative effects of climate change. Furthermore, to mitigate the negative impacts on economic development, the gross domestic product of India can be increased thanks to bio-based economy (Lee, 2016). The reduction of organic pollution, an increasing threat in India, can be lead by improved production and application of bioplastics that can substitute traditional plastic in many application fields (Philp, 2014). These next-years perspectives require to develop programs of crop protection that can be feasible according to climate change in India and that can be integrated or can support development of bio-industry. While projected temperatures in South Asia for 2030 should help to fit best environmental requirement for soil solarization (temperatures should increase by more than $1^{\circ} \mathrm{C}$ ), a more than $5 \%$ of decrease in precipitation (Lobell et al., 2008) should create issue for soil preparation. However, successful of soil solarization trials in arid zone of India such as Rajasthan (Israel and Lodha, 2004; Israel et al., 2005) indicate as low precipitation did not compromise results, while increase of temperatures could support solarization in moist sub-humid zones such as Himachal Pradesh. Furthermore, the Indian perspective in bioplastic production could support application and development of biodegradable films for solarization. Biodegradable films showed a good potential of using in place of plastic films, but further development is needed to obtain performances comparable to conventional techniques (Bonanomi et al., 2008), and plastic waste management of Indian rural area may have benefits from bio-industry development.

Compared to others world areas in which application of biodegradable films cannot be paired with large-scale bioplastic production (i.e., Mediterranean area), India perfectly fits into requirement for soil solarization application and potential bioorganic plastic production, due to large areas in which wheat or maize are cultivated. In a 2050 scenario, the bioplastic will be mainly produced in Asiatic continent, and India is showing the higher rate of increase per year (more than 5\%) in the bioplastic sector (Lee, 2016). Thus, a local production and local consumption model should be achievable for biodegradable films, supporting development of national economy.

\section{CONCLUDING REMARKS}

Soil solarization trials reported in this review were not systematically carried out within a national framework, whereas some soil solarization benefits (i.e., reduced environmental impact) or economies of scale (i.e., supplying and disposal of plastic films or irrigation systems) are highlighted by its application at large scale. Organizations such as NCPAH are crucial actors for the widespread use of soil solarization among farmers and drive its development in Indian rural policy, with positive contribution in achieving food sovereignty. Food sovereignty model cannot be yet firmly defined by set of policies (Windfuhr and Jonsén, 2005) but it represents an essential topic to current discussion of strategies to achieve food security in rural areas. India is anything that unrelated to this debate and associations of farmers linked to La Via Campesina are present, such as the Karnataka State Farmers association which is the most visible organization in South Asia (Borras, 2008). Opinions against chemical farming and urgency to gain Indian food sovereignty are key-topic of the Vandana Shiva's Agenda Anna Swaraj (Food Sovereignty) 2020, but low chemical farming is also promoted by Indian rural policy, even effects are limited (Agarwal, 2014).

Soil solarization cannot be considered as a high-tech solution, with interesting perspective in terms of sovereignty. Crop protection using conventional methods tends to bind farmers to agrochemical industry that, mostly, is not hailing from developing countries. Furthermore, the economic recession in late 2000s made technological sovereignty for plant defense hard to achieve, in particular in Countries in which industrialization is not so widespread. Therefore, technological sovereignty for plant protection is not typical for many South Asia countries, while it may represents a useful resource for sustainability. The use of crop protection techniques should be evaluated with regard to novel approach of sustainability in agricultures; among them, agroecology carefully specify the part of technology in food production. As defined by Altieri and Toledo (2011), sovereignty in technology-and in energetic sources-is a crucial part to achieve food independence of agricultural societies. Fundamentals of this theory involve the use of ecosystem richness, considering biodiversity as an effective production factor and strongly limiting-and if possible, excluding-the use of third-parties inputs. The implementation of technological input locally identified can lead to independence in food production and may reduce risk of food safety (Altieri and Toledo, 2011).

Soil solarization may represent crop protection techniques that substantially relay on locally available resources-that can be considered as local as solar radiation-and it does not generate dependence of farmers to agrochemical producers. Furthermore, the contribution of soil solarization to fill the yield gap may play a significant role in achieving Indian food sovereignty. To conclude, the literature reviewed in this paper indicates more than encouraging effects on production and protection of Indian crops, which can be feasible according to climate change in India and that can be integrated or can support development of national bio-industry. Further trials and communication plans can drive farmers' growth of confidence toward this protection method.

\section{AUTHOR CONTRIBUTIONS}

HG, IA, and AL conceived the review; HG and IA analyzed the literature data; HG, IA, and AL prepared the manuscript; $H G$, LDB, and AL edited the manuscript. 


\section{REFERENCES}

Abdel-Rahim, M. F., Satour, M. M., Mickail, K. Y., El-Erakis, S. A., Grinstein, A., and Katan, J. (1988). Effectiveness of soil solarization in furrow- irrigated Egyptian soils. Plant Dis. 72, 143-145. doi: 10.1094/PD-72-0143

Agarwal, A., Prajapati, R., Singh, O. P., Raza, S. K., and Thakur, L. K. (2015). Pesticide residue in water-a challenging task in India. Environ. Monit. Assess. 187:54. doi: 10.1007/s10661-015-4287-y

Agarwal, B. (2014). Food sovereignty, food security and democratic choice: critical contradictions, difficult conciliations. J. Peasant Stud. 41, 1247-1268. doi: 10. 1080/03066150.2013.876996

Ahmad, Y., Hameed, A., and Aslam, M. (1996). Effect of soil solarization on corn stalk rot. Plant Soil 179, 17-24. doi: 10.1007/BF00011638

Altieri, M., and Toledo, V. M. (2011). The agroecological revolution in Latin America: rescuing nature, ensuring food sovereignty and empowering peasants. J. Peasant Stud. 38, 587-612. doi: 10.1080/03066150.2011. 582947

Aon, M. A., Cabello, M. N., Sarena, D. E., Colaneri, A. C., Franco, M. G., Burgos, J. L., et al. (2001). Spatio-temporal patterns of soil microbial and enzymatic activities in an agricultural soil. Appl. Soil Ecol. 18, 239-254. doi: 10.1016/S09291393(01)00153-6

Aon, M. A., and Colaneri, A. C. (2001). Temporal and spatial evolution of enzymatic activities and physico-chemical properties in an agricultural soil. Appl. Soil Ecol. 18, 255-270. doi: 10.1016/S0929-1393(01)00161-5

Arora, A., and Tomar, S. S. (2012). Effect of soil solarization on weed seed bank in soil. Indian J. Weed Sci. 44, 122-123.

Arora, A., and Yaduraju, N. T. (1998). High-temperature effects on germination and viability of weed seeds in soil. J. Agron. Crop Sci. 181, 35-43. doi: 10.1111/j. 1439-037X.1998.tb00395.x

Aujla, I. S., Thind, T. S., and Kumar, P. (2011). Disease scenario in vegetables under protected cultivation in Punjab. Plant Dis. Res. 25, 185-187.

Benlloglu, S., Boz, O., Yildiz, A., Kaskavalci, G., and Benlioglu, K. (2005). Alternative soil solarization treatments for the control of soil- borne diseases and weeds of strawberry in the Western Anatolia of Turkey. J. Phytopathol. 153, 423-430. doi: 10.1111/j.1439-0434.2005.00995.x

Biradar, I. B., and Hosamani, M. M. (1997). Effect of soil solarization on weed control and its effects on growth yield of groundnut (Arachis hypogaea L.). Karnataka J. Agric. Sci. 10, 966-970.

Bohra, M. D., Harsh, L. N., and Lodha, S. (1996). Solar heating for controlling pathogens of jojoba (Simmondsia chinensis) in nursery soils. Indian J. Agric. Sci. $66,679-683$.

Bonanomi, G., Chiurazzi, M., Caporaso, S., Del Sorbo, G., Moschetti, G., and Scala, F. (2008). Soil solarization with biodegradable materials and its impact on soil microbial communities. Soil Biol. Biochem. 40, 1989-1998. doi: 10.1016/ j.soilbio.2008.02.009

Borras, S. M. (2008). La vía campesina and its global campaign for agrarian reform. J. Agrar. Change 8, 258-289. doi: 10.1111/j.1471-0366.2008.00170.x

Camprubí, A., Estaún, V., El Bakali, M. A., Garcia-Figueres, F., and Calvet, C. (2007). Alternative strawberry production using solarization, metham sodium and beneficial soil microbes as plant protection methods. Agron. Sustain. Dev. 27, 179-184. doi: 10.1051/agro:2007007

Cassman, K. G. (1999). Ecological intensification of cereal production systems: yield potential, soil quality, and precision agriculture. Proc. Natl. Acad. Sci. U.S.A. 96, 5952-5959. doi: 10.1073/pnas.96.11.5952

Chakraborty, M. R., Chatterjee, N. C., and Quimio, T. H. (2009). Integrated management of fusarial wilt of eggplant (Solanum melongena) with soil solarization. Micol. Aplicada Int. 21, 25-36.

Chauhan, Y. S., and Ghaffar, M. A. (2002). Solar heating of seeds- a low cost method to control bruchid (Callosobruchus spp.) attack during storage of pigeonpea. J. Stored Prod. Res. 38, 87-91. doi: 10.1016/S0022-474X(01) 00005-4

Chauhan, Y. S., Nene, Y. L., Johansen, C., Haware, M. P., Saxena, N. P., Sardar, S., et al. (1988). Effects of Soil Solarization on Pigeonpea and Chickpea. Research Bulletin No. 11. Patancheru: International Crops Research Institute for the Semi-Arid Tropics.

Chellemi, D. O., and Mirusso, J. (2006). Optimizing soil disinfection producers for fresh market tomato and pepper production. Plant Dis. 90, 668-674. doi: 10.1094/PD-90-0668
Chen, Y., and Katan, J. (1980). Effect of solar heating of soils by transparent poliethilene mulching on their chemical properties. Soil Sci. 130, 271-277. doi: 10.1097/00010694-198011000-00007

D'Addabbo, T., Miccolis, V., Basile, M., and Candido, V. (2010). "Soil solarization and sustainable agriculture," in Sociology, Organic Farming, Climate Change, and Soil Science, ed. E. Lichtfocus (Dordrecht: Springer), 217-274.

Daelemans, A. (1989). Soil solarization in West-Cameroon: effect on weed control, some chemical properties and pathogens of the soil. Acta Hortic. 255, 169-175. doi: 10.17660/ActaHortic.1989.255.19

Das, T. K., and Yaduraju, N. T. (2008). Effect of soil solarization and crop husbandry practices on weed species competition and dynamics in soybeanwheat cropping system. Indian J. Weed Sci. 40, 1-5.

Devi, T. R., and Chhetry, G. K. N. (2013). Effect of certain agronomic practices for the management of wilt of pigeonpea in Manipur agro-climatic conditions. IOSR J. Eng. 3, 21-23. doi: 10.9790/3021-03442123

Domínguez, P., Miranda, L., Soria, C., de los Santos, B., Chamorro, M., Romero, F., et al. (2014). Soil biosolarization for sustainable strawberry production. Agron. Sustain. Dev. 34, 821-829. doi: 10.1007/s13593-014-0211-z

Dubey, R. C., Kumar, H., and Pandey, R. R. (2009). Combined effect of soil solarization and neem amendment on survival of Macrophomina phaseolina sclerotia and growth of soybean. Nat. Sci. 7, 52-57.

Dwivedi, R. (1993). "The soil mycoflora of sugarcane in relation to soil solarization (Abstr.). Symposium (Botany-section)," in Proceedings 80th Indian Science Congress Association, Goa, 3-8 January, ed. R. S. Dwivedi (Calcutta: ISCA), 47.

Dwivedi, R. (1998). Soil solarization and the survival of two fungal pathogens of sugarcane and the composition of the soil fungal community. Soil Biol. Biochem. 30, 1849-1852. doi: 10.1016/S0038-0717(98)00044-3

Dwivedi, R. S., and Dubey, R. C. (1987). Effect of soil solarization on the population dynamics of Macrophomina phaseolina (Tassi) Goid and general soil mycoflora. Int. J. Trop. Plant Dis. 5, 67-73.

Dwivedi, S. K. (1991a). Effect of solar heating of soil on the dynamics of the soil mycoflora. J. Mycopathol. Res. 29, 93-96.

Dwivedi, S. K. (1991b). Studies on population dynamics of Fusarium oxysporum $\mathrm{f}$. sp. lycopersici in solar heated soil. Natl. Acad. Sci. Lett. 14, 235-237.

Dwivedi, S. K. (1993). Soil solarization adversely affects some fungal pathogens causing wilt disease of guava (Psidium guajava L). Soil Biol. Biochem. 25, 1635-1636. doi: 10.1016/0038-0717(93)90019-8

Elmore, C. L., Stapleton, J. J., Bell, C. E., and DeVay, J. E. (1997). Soil Solarization, a Nonpesticidal Method for Controlling Diseases, Nematodes and Weeds. Oakland, CA: University of California.

FAO (2010). The Impact of the Economic and Financial Crises on Agriculture and Food Security in Europe and Central Asia: a Compendium. Available at: http://www.fao.org/fileadmin/user_upload/Europe/documents/Publications/ REU_TP/Compendium_en.pdf

Freeman, S., and Katan, J. (1988). Weakening effect on propagules of Fusarium by sublethal heating. Phytopathology 78, 1656-1661. doi: 10.1094/Phyto78-1656

Gade, R. M., and Giri, G. K. (2005). Integration of soil solarization and fungicides for management of Phytophthora sp. in citrus nursery. Indian Phytopathol. 58, 114-116.

Gamliel, A., Austerweil, M., and Kritzman, G. (2000). Non-chemical approach to soil-bornepest management-organic amendments. Crop Protec. 19, 847-853. doi: 10.1016/S0261-2194(00)00112-5

Gaur, H. S., and Dhingra, A. (1991). Management of Meloidogyne incognita and Rotylenchulus reniformis in nursery-beds by soil solarization and organic soil amendments. Rev. Nematol. 14, 189-195.

Gelsomino, A., Badalucco, L., Landi, L., and Cacco, G. (2006). Soil carbon, nitrogen and phosphorus dynamics as affected by solarization alone and combined with organic amendment. Plant Soil 279, 307-325. doi: 10.1007/s11104-0052155-1

Ghorai, A. K. (2007). Weed management of jute (Crochorus olitorius) by soil solarization. Indian J. Agric. Sci. 77, 390-392.

Gill, H. K., and Garg, H. (2014). "Pesticide: environmental impacts and management strategies," in Pesticides- Toxic Effects, eds S. Solenski and M. L. Larramenday (Rijeka: InTech), 187-230.

Gill, H. K., and McSorley, R. (2010). Effect of integrating soil solarization and organic mulching on the soil surface insect community. Florida Entomol. 93, 308-309. doi: 10.1653/024.093.0224 
Gill, H. K., McSorley, R., and Treadwell, D. D. (2009). Comparative performance of different plastic films for soil solarization and weed suppression. HortTechnology 19, 769-774.

Godfray, H. C. J., Beddington, J. R., Crute, I. R., Haddad, L., Lawrence, D., Muir, J. F., et al. (2010). Food security: the challenge of feeding 9 billion people. Science 327, 812-818. doi: 10.1126/science.1185383

Gupta, A. K., and Khosla, K. (2007). Integration of soil solarization and potential native antagonist for the management of crown gall on cherry rootstock colt. Sci. Hortic. 112, 51-57. doi: 10.1016/j.scienta.2006.12.004

Gupta, V. V. S. R., and Yeates, G. W. (1997). "Soil microfauna as bioindicators of soil health," in Biological Indicators of Soil Health, eds C. E. Pankhurst, B. M. Doube, and V. V. S. R. Gupta (Wallingford: CABI).

Horiuchi, S. (1984). "Soil solarization for suppressing soil-bornediseases in Japan," in The Ecology and Treatment of Soil-Bornediseases in Asia. Technical Bulletin No.78, (Taiwan: Food and Fertilizer Technology Center), 11-23.

Israel, S., and Lodha, S. (2004). Factors influencing population dynamics of Fusarium oxysporum f.sp. cumini in the presence and absence of cumin crop in arid soils. Phytopathol. Mediter. 43, 3-13.

Israel, S., Mawar, R., and Lodha, S. (2005). Soil solarisation, amendments and bio-control agents for the control of Macrophomina phaseolina and Fusarium oxysporum f.sp. cumini in aridisols. Ann. Appl. Biol. 146, 481-491. doi: 10.1111/ j.1744-7348.2005.040127.x

Israel, S., Mawar, R., and Lodha, S. (2011). Combining sub-lethal heating and onfarm wastes: effects on Fusarium oxysporum f.sp. cumini causing wilt of cumin. Phytoparasitica 39, 73-82. doi: 10.1007/s12600-010-0126-4

Jayaraj, J., and Radhakrishnan, N. V. (2008). Enhanced activity of introduced biocontrol agents in solarized soils and its implications on the integrated control of tomato damping-off caused by Pythium spp. Plant Soil 304, 189-197. doi: 10.1007/s11104-008-9539-y

Kamaluddeen, and Simon, S. (2013). Effect of soil solarization, bio-agents and organic composts on blast of paddy. Int. J. Bot. Res. 3, 21-28.

Kapoor, R. T. (2013). "Soil solarization: eco-friendly technology for farmers in agriculture for pest management," in Proceedings of 2nd International Conference on Advances in Biological and Pharmaceutical Sciences (ICABPS 2013), Hong Kong.

Karegowda, C., Venkatesh, and Gurumurthy, B. R. (2008). Integrated management of damping-off disease of FCV tobacco in nursery. Karnataka J. Agric. Sci. 21, 299-300.

Katan, J. (1981). Solar heating (solarization) of the soil for control of soilbornepests. Annu. Rev. Phytopathol. 19, 211-236. doi: 10.1146/annurev.py.19. 090181.001235

Katan, J. (1987). "Soil solarization," in Innovative Approaches to Plant Disease Control, ed. I. Chet (New York, NY: John Wiley \& Sons), 77-105.

Katan, J., Greenberger, A., Alon, A., and Grinstein, A. (1976). Solar heating by polyethylene mulching for the control of disease caused by soil-borne pathogens. Phytopathology 76, 683-688. doi: 10.1094/Phyto-66-683

Khan, A. R., Ghora, A. K., and Singh, S. R. (2000). Improvement of crop and soil sustainability through green manuring in rainfed lowland rice ecosystem. Agrochimica 44, 21-29.

Khan, A. R., Ghorai, A. K., Srivastava, R. C., and Singh, S. R. (1997). Development of eco-friendly and non-hazardous weed control technology for lowland rice by smothering through LDPE film. J. Agron. Crop Sci. 178, 73-78. doi: 10.1111/j. 1439-037X.1997.tb00353.x

Khan, A. R., Srivastava, R. C., Ghorai, A. K., and Singh, S. R. (2003). Efficient soil solarization for weed control in the rain-fed upland rice ecosystem. Int. Agrophys. 17, 99-103.

Kumar, B., Yaduraju, N. T., Ahuja, N., and Prasad, D. (1993). Effect of soil solarization on weeds and nematodes under tropical Indian conditions. Weed Res. 33, 423-429. doi: 10.1111/j.1365-3180.1993.tb01958.x

Kumar, M., and Das, T. K. (2008). Integrated weed management for system productivity and economics in soybean (Glycine max) - wheat (Triticum aestivum) system. Indian J. Agron. 53, 189-194.

Kumar, M., Das, T. K., and Yaduraju, N. T. (2012a). An integrated approach for management of Cyperus rotundus (pruple nutsedge) in soybean-wheat cropping system. Crop Protect. 33, 74-81. doi: 10.1016/j.cropro.2011.11.016

Kumar, M., Das, T. K., and Yaduraju, N. T. (2012b). Summer and rainy-season weed control effects on weeds in soybean and succeeding wheat. Pestic. Res. J. $24,177-182$.
Kumar, R., and Sharma, J. (2005). Effect of soil solarization on true potato (Solanum tuberosum L.) seed germination, seedling growth, weed population and tuber yield. Potato Res. 48, 15-23. doi: 10.1007/BF02733678

Kumar, V. K. K., Nanjappa, H. V., and Ramachandrappa, B. K. (2001). Effect of soil solarization on weed control and its aftermath effect on yield and yield components of tomato. Karnataka J. Agric. Sci. 14, 910-915.

Lale, N. E. S., and Ajayi, F. A. (2001). Suppression of development of Callosobruchus maculatus (F.) (Col.: Bruchidae) in bambara groundnut seeds exposed to solar heat in the Nigerian savanna. J. Pest Sci. 74, 133-137. doi: 10.1046/j.1439-0280.2001.01028.x

Lee, D. H. (2016). Bio-based economies in Asia: Economic analysis of development of bio-based industry in China, India, Japan, Korea, Malaysia and Taiwan. Int. J. Hydr. Energy 41, 4333-4346. doi: 10.1016/j.ijhydene.2015.10.048

Linke, K. H., Saxena, M. C., Sauerborn, J., and Masri, H. (1991). "Effect of soil solarization on the yield of food legumes and on pest control," in Proceedings of the First International Conference on Soil Solarization, Amman, Jordan, FAO Plant Protection and Production Paper 109, eds J. E. DeVay, J. J. Stapleton, and C. L. Elmore (Rome: FAO), 139-154.

Lobell, D. B., Burke, M. B., Tebaldi, C., Mastrandrea, M. D., Falcon, W. P., and Naylor, R. L. (2008). Prioritizing climate change adaptation needs for food security in 2030. Science 319, 607-610. doi: 10.1126/science.1152339

Lodha, S. (1995). Soil solarization, summer irrigation and amendments for the control of Fusarium oxysporum f. sp. cumini and Macrophomina phaseolina in arid soils. Crop Prot. 14, 215-219. doi: 10.1016/0261-2194(95)00014-D

Lodha, S., Sharma, S. K., and Aggarwal, R. K. (1997). Solarization and natural heating of irrigated soil amended with cruciferous residues for improved control of Macrophomina phaseolina. Plant Pathol. 46, 186-190. doi: 10.1046/j. 1365-3059.1997.d01-223.x

Lodha, S., Sharma, S. K., Mathur, B. K., and Aggarwal, R. K. (2003). Integrating sub-lethal heating with Brassica amendments and summer irrigation for control of Macrophomina phaseolina. Plant Soil 256, 423-430. doi: 10.1023/A: 1026181009751

Lodha, S., and Solanki, K. R. (1992). Influence of solar heating on the control of Macrophomina phaseolina and weeds in arid environment. Indian J. Agric. Sci. $62,838-843$.

Luvisi, A., Panattoni, A., and Materazz, A. (2015). Heat treatments for sustainable control of soil viruses. Agron. Sustain. Dev. 35, 657-666. doi: 10.1007/s13593014-0258-x

Maetz, M., Aguirre, M., Kim, S., Matinroshan, Y., Pangrazio, G., and Pernechele, V. (2011). Food and Agricultural Policy Trends After the 2008 Food Security Crisis: Renewed Attention to Agricultural Development. Available at: http://www.fao. org/3/a-ap237e.pdf

Mauromicale, G., Lo Monaco, A., and Longo, A. M. G. (2010). Improved efficiency of soil solarization for growth and yield of greenhouse tomatoes. Agron. Sustain. Dev. 30, 753-761. doi: 10.1051/agro/2010015

Mawar, R., and Lodha, S. (2002). Brassica amendments and summer irrigation for the control of Macrophomina phaseolina and Fusarium oxysporum f.sp. cumini in hot arid regions. Phytopathol. Mediterr. 41, 45-54.

Mawar, R., and Lodha, S. (2009). Prior weakening of Macrophomina phaseolina and Fusarium propagules for enhancing efficiency of Brassica amendments. Crop Protect. 28, 812-817. doi: 10.1016/j.cropro.2009.06.008

McFarlane, J. A. (1989). Guidelines for Pest Management Research to Reduce Stored Food Losses Caused by Insects and Mites. Bulletin No. 22. Chatham: Overseas Development Natural Resources Institute.

McGovern, R. J., and McSorley, R. (1997). "Physical methods of soil sterilization for disease management including soil solarization," in Environmentally Safe Approaches to Crop Disease Control, eds N. A. Rechcigl and J. E. Rechcigl (Boca Raton, FL: CRC Press, Inc), 283-313.

Minarro, M., and Dapena, E. (2003). Effects of groundcover management on ground beetles (Coleoptera: Carabidae) in an apple orchard. Appl. Soil Ecol. 23, 111-117. doi: 10.1016/S0929-1393(03)00025-8

Mudalagiriyappa Nanjappa, H. V., and Ramachandrappa, B. K. (2001). Integrated weed management in groundnut- French bean cropping system. Karnataka J. Agric. Sci. 14, 286-289.

Nair, S. K., Peethambaran, C. K., Geetha, D., Nayar, K., and Wilson, K. I. (1990). Effect of soil solarization on nodulation, infection by mycorrhizal fungi and yield of cowpea. Plant Soil 125, 153-154. doi: 10.1007/BF00 010757 
Patel, D. J., Patel, H. R., Patel, S. K., and Gakwana, M. (1991). Soil solarization through clear polythene tarping for management of root-knot disease in tobacco nursery. Tob. Sci. 35, 63-64.

Patel, H. R., Lakshminarayana, R., and Makwana, M. G. (1995). The control of nematodes by soil solarization for growing tobacco seedlings. Plasticulture $106,2-6$.

Philp, J. (2014). Policies for bioplastics in the context of a bioeconomy. Ind. Biotechnol. 10, 19-21. doi: 10.1089/ind.2013.1612

Pillai, K. G., and Rao, M. V. (1974). "Yield reduction in rice due to weeds," in Proceedings of the International Rice Research Conference, Manila: IRRI.

Pingali, P. (2006). Westernization of Asian diets and the transformation of food systems: implications for research and policy. Food Policy 32, 281-298. doi: 10.1016/j.foodpol.2006.08.001

Pinstrup-Andersen, P. (2009). Food security: definition and measurement. Food Security 1, 5-7. doi: 10.1007/s12571-008-0002-y

Poll, C., Ingwersen, J., Stemmer, M., Gerzabek, M. H., and Kandeler, E. (2006). Mechanisms of solute transport affect small-scale abundance and function of soil microorganisms in the detritusphere. Eur. J. Soil Sci. 57, 583-595. doi: 10.1111/j.1365-2389.2006.00835.x

Raj, H., and Sharma, S. D. (2005). "Integrated management of collar and root rot (Sclerotium rolfsii) of strawberry," in Proceedings VIIth on Temperature Zone Fruits in the Tropics and Subtropics, Vol. 696, eds J. S. Chauhan, S. D. Sharma, R. C. Sharma, A. S. Rehalia, and K. Kumar (Leuven: International Society for Horticultural Science), 375-379.

Raj, H., and Sharma, S. D. (2009). Integration of soil solarization and chemical sterilization with beneficial microorganisms for the control of white root rot and growth of nursery apple. Sci. Hortic. 119, 126-131. doi: 10.1016/j.scienta. 2008.07.025

Raju, B. M. K., Rao, K. V., Venkateswarlu, B., Rao, A. V. M. S., Rama Rao, C. A., Rao, V. U. M., et al. (2013). Revisiting climatic classification in India: a district-level analysis. Curr. Sci. 105, 492-495.

Ray, D. K., Mueller, N. D., West, P. C., and Foley, J. A. (2013). Yield trends are insufficient to double global crop production by 2050. PLOS ONE 8:e66428. doi: 10.1371 /journal.pone.0066428

Scopa, A., and Dumontet, S. (2007). Soil solarization: effects on soil microbiological parameters. J. Plant Nutr. 30, 537-547. doi: 10.1080/01904160701 209212

Shane, M., Liefert, W., Morehart, M., Peters, M., Dillard, J., Torgerson, D., et al. (2009). The 2008/2009 World Economic Crisis: What It Means for U.S. Agriculture. Available at: http://www.ers.usda.gov/media/160647/wrs0902.pdf

Sharma, S. B., and Nene, Y. L. (1990). Effects of soil solarization on nematodes parasitic to chickpea and pigeonpea. J. Nematol. 22, 658-664.

Sharma, S. D., Kumar, P., Bhardwaj, S. K., and Chandel, A. (2011a). Symbiotic effectiveness of arbuscular mycorrhizal technology and Azotobacterization in citrus nursery production under soil disinfestation and moisture conservation practices. Sci. Hortic. 132, 27-36. doi: 10.1016/j.scienta.2011. 09.033

Sharma, S. D., Kumar, P., Bhardwaj, S. K., and Yadav, S. K. (2011b). Screening and selecting novel AM fungi and Azotobacter strain for inoculating apple under soil solarization and chemical disinfestation with mulch practices for sustainable nursery management. Sci. Hortic. 130, 164-174. doi: 10.1016/j. scienta.2011.06.032

Sharma, S. K., Kishore, D. K., and Pramanick, K. K. (2005). "Effect of soil solarization on soil microflora and survival of Dematophora necatrix in temperate fruit nurseries," in Proceeding of VIIth International Symposium on Temperate Zone Fruits in the Tropics and Subtropics, Vol. 696, eds J. S. Chauhan, S. D. Sharma, R. C. Sharma, A. S. Rehalia, and K. Kumar (Leuven: International Society for Horticultural Science), 381-386.

Shukla, A., and Dwivedi, S. K. (2011). Implication of solarization against soil borne Fusaria in leguminous crop fields in Kalli paschim village in Lucknow, India: a tropical country. Int. J. Environ. Sci. 2, 1083-1092.
Singh, R. (2006). Use of soil solarization in weed management on soyabean under Indian conditions. Trop. Sci. 46, 70-73. doi: 10.1002/ts.28

Singh, R. K., Sharma, J., Jha, S. K., and Singh, A. K. (2012). Solarization technique: its use in the multiplication of in vitro planting materials. Curr. Sci. 102, $1433-1436$.

Singh, R. K., Sharma, J., Singh, G. K., and Trehan, S. P. (2009). Effect of soil solarization on multiplication of in-vitro planting materials of potato under field conditions. Potato J. 36, 143-148.

Singh, Y. (2008). Effect of soil solarization and biocontrol agents on plant growth and management of anthracnose of sorghum. Int. J. Agric. Sci. 4, 188-191.

Soumya, T. M., Nanjappa, H. V., and Ramachandrappa, B. K. (2004). Effect of soil solarization on weed count, weed dry weight and pod yield of groundnut. Karnataka J. Agric. Sci. 17, 548-550.

Stapleton, J. J. (1997). "Solarization: an implementable alternative for soil disinfestation," in Biological and Cultural Tests for Control of Plant Diseases, Vol. 12, ed. C. Canaday (St. Paul, MN: APS).

Stapleton, J. J., and DeVay, J. E. (1986). Soil solarization: a non-chemical approach for management of plant pathogens and pests. Crop Protec. 5, 190-198. doi: 10.1016/0261-2194(86)90101-8

Stapleton, J. J., and DeVay, J. E. (1995). "Soil solarization: a natural mechanism of integrated pest management," in Novel Approaches to Integrated Pest Management, ed. R. Reuveni (Boca Raton, FL: Lewis).

Stapleton, J. J., and Heald, C. M. (1991). "Management of phytopathogenic nematodes by soil solarization," in Soil Solarization, eds J. Katan and J. E. DeVay (Boca Raton, FL: CRC Press Inc), 51-59.

Stapleton, J. J., Quick, J., and DeVay, J. E. (1985). Soil solarzation: effects on soil properties, crop fertilization and plant growth. Soil Biol. Biochem. 17, 369-373. doi: 10.1016/0038-0717(85)90075-6

Stevens, C., Khan, V. A., Cody, R. M., Lu, J. Y., Haung, Z., Tang, A. Y., et al. (1991). Soil solarization: the effects of organic amendments on microflora of soil rhizosphere of cole crops. Proc. Am. Soc. Plast. 23, 281-287.

Subrahmaniyan, K., Kalaiselvan, P., and Arulmozhi, N. (2002). Weed control in groundnut (Arachis hypogaea L.) with polyethylene film mulching. Int. J. Pest Manag. 48, 261-264. doi: 10.1080/09670870210133698

Summers, C. G., Newton, A. S., Mitchell, J. P., and Stapleton, J. J. (2010). Population dynamics of arthropods associated with early-season tomato plants as influenced by soil surface microenvironment. Crop Protect. 29, 249-254. doi: 10.1016/j.cropro.2009.11.012

Velmourougane, K., Venugopalan, M. V., Bhattacharyya, T., Sakar, D., Pal, D. K., Sahu, A., et al. (2013). Soil dehydrogenase activity in agro-ecological sub regions of black soil regions in India. Geoderma 19, 186-192. doi: 10.1016/j.geoderma. 2013.01.011

Verma, R. K., Thakur, A. K., Turkane, D., and Rajput, P. S. (2010). Solarization of nursery soil induces production of fruit bodies of mushrooms and enhances growth of tropical forest tree seedlings. Ann. For. Res. 53, 117-126.

Weller, D. M., Raaijmakers, J. M., Gardener, B. B., and Thomashow, L. S. (2002). Microbial populations responsible for specific soil suppressiveness to plant pathogens. Annu. Rev. Phytopathol. 40, 309-348. doi: 10.1146/annurev.phyto. 40.030402.110010

Windfuhr, M., and Jonsén, J. (2005). Food Sovereignity: Towards Democracy in Localized Food Systems. Available at: http://www.ukabc.org/foodsovpaper.htm

Conflict of Interest Statement: The authors declare that the research was conducted in the absence of any commercial or financial relationships that could be construed as a potential conflict of interest.

Copyright (C) 2017 Gill, Aujla, De Bellis and Luvisi. This is an open-access article distributed under the terms of the Creative Commons Attribution License (CC BY). The use, distribution or reproduction in other forums is permitted, provided the original author(s) or licensor are credited and that the original publication in this journal is cited, in accordance with accepted academic practice. No use, distribution or reproduction is permitted which does not comply with these terms. 